\title{
Effect of work-induced hypertrophy on muscle glucose metabolism in lean and obese mice
}

\author{
G. Augert ${ }^{1}$, G. Van de Werve ${ }^{2}$ and Y.Le Marchand-Brustel ${ }^{1}$ \\ ${ }^{1}$ Unité de Recherche sur les Hormones Polypeptidiques et la Physiopathologie Endocrinienne, Institut National de la Santé et de la Recherche \\ Médicale, Faculty of Medicine (Pasteur) Nice, France, and ${ }^{2}$ Laboratoires de Recherches Métaboliques, University of Geneva, Switzerland
}

Summary. The effect of work-induced hypertrophy (without any concomitant change in circulating parameters) on skeletal muscle metabolism was studied in lean mice and in goldthioglucose obese-mice. Soleus muscle was functionally overloaded in one leg by tenotomy of gastrocnemius muscle 4 days before muscle isolation, muscle in the other leg being used as control. Basal deoxyglucose uptake and glycolysis were markedly increased in overloaded muscles compared with control muscles, together with a ten-fold increase in fructose 2-6 bisphosphate content. In the presence of maximally effective insulin concentrations, deoxyglucose uptake and glycolysis were identical in overloaded and control muscles of lean mice, while the effects of overload and insulin were partly additive in muscles of goldthioglucose-obese mice. The sensitivity to insulin and insulin binding to muscles were not modified in overloaded muscles. Insulin-stimulated glycogenogenesis was decreased by about $50 \%$ probably due to a lower amount of glycogen synthase in overloaded than in control muscles. Thus, in muscles of goldthioglucose-obese mice work-induced hypertrophy increased the response to maximal insulin concentrations without modifying the altered insulin sensitivity and decreased insulin binding.

Key words: Insulin, insulin resistance, obesity, exercise, glucose metabolism, glycogen synthase, fructose 2-6 bisphosphate, skeletal muscle, goldthioglucose obese mice, hypertrophy.
Muscle tissue from obese hyperinsulinaemic animals displays a number of abnormalities including a defect in glucose transport and utilization, an altered aminoacid transport and a decrease in insulin binding [1-5]. This results in decreased insulin sensitivity and responsiveness of this tissue, which largely contribute to the marked insulin resistance observed in genetically-or experimentally-induced obese syndromes. In normal man and animals it has been demonstrated repeatedly that physical training is associated with an increase in overall insulin sensitivity in vivo [6-11]; skeletal muscle seems to contribute essentially to this increased insulin sensitivity [9-11]. In obese animals, although physical training by treadmill running or by swimming improves tolerance, insulin resistance in muscle is either unchanged [7, 8] or partly reversed [7].

In the present study, we used the following approach. By cutting the connection of the gastrocnemius muscle to the ankle of one single leg, an important work load is applied to the soleus muscle which undergoes rapid compensatory hypertrophy [12]. Taking advantage of this experimental technique, we compared a hypertrophied, overloaded muscle in one leg with a control muscle in the other within the same animal, and we studied the effect of this form of exercise on glucose uptake and metabolism in lean and goldthioglucose-obese mice.

\section{Materials and methods}

\section{Animals}

Male Swiss albino mice (age 7-8 weeks) were fed ad libitum with laboratory chow (Usine d'Alimentation Rationnelle, Villemoisson, Epinay/Orge, France) and maintained in a constant-temperature animal room $\left(23^{\circ} \mathrm{C}\right)$, with a fixed 12 -h artificial light cycle (07.00-19.00 hours) until they were killed (9.00-11.00 hours). Mice were rendered obese by a double injection of goldthioglucose given at 3 weeks of age [3] and were used at 25-30 weeks when obesity was fully expressed.

\section{Surgical procedure and soleus muscle isolation}

Mice were anaesthetised with ether. On the tenotomy hind limb, the tendon of the gastrocnemius muscle was dissected free from the soleus, cut and separated to prevent tendon re-approximation by fibrosis [12]. Following tenotomy of the gastrocnemius, the work load on the soleus muscle was increased and the muscle underwent rapid compensatory growth. Sham operations were not routinely performed because pilot experiments revealed no difference between muscles from sham-operated or non-operated legs (data not shown). Four days after tenotomy, the mice were killed by cervical dislocation and the soleus muscles were isolated and incubated as described previously $[1,3]$. Muscles were isolated free from the leg, attached to a stainless steel holder and suspended individually in flat-bottomed glass tubes. Each muscle was immersed in $1 \mathrm{ml}$ of Krebs-Ringer bicarbonate buffer ( $\mathrm{pH}$ 7.4) [13] containing $10 \mathrm{mg} / \mathrm{ml}$ defatted bovine albumin (KRBBSA) and the additions specified for each experiment. The tubes were sealed with rubber stoppers and gassed with $\mathrm{O}_{2}: \mathrm{CO}_{2}(95 \%: 5 \%$, vol/ vol) during a pre-incubation period of $15 \mathrm{~min}$ and the first $10 \mathrm{~min}$ of the incubation periods described as follows. 


\section{Deoxyglucose uptake studies}

Muscles were first incubated for $60 \mathrm{~min}$ at $37^{\circ} \mathrm{C}$ in the medium described above, supplemented with pyruvate $(2 \mathrm{mmol} / \mathrm{l})$ and containing varying concentrations of insulin. They were then incubated for 15 min with 2-deoxy-D-(1- $\left.{ }^{14} \mathrm{C}\right)$-glucose $(0.5 \mathrm{mmol} / 1,0.1 \mu \mathrm{Ci} / \mathrm{ml})$. At the end of the incubation, muscles were washed for $30 \mathrm{~min}$ in ice-cold $\mathrm{NaCl}$ solution $(154 \mathrm{mmol} / \mathrm{l})$, dissolved in $0.3 \mathrm{ml}$ of $\mathrm{NaOH}(1 \mathrm{~mol} / \mathrm{l})$ and an aliquot sample was counted [3].

\section{Glucose metabolism studies}

Glucose utilization by muscle was studied by measuring simultaneously the rate of formation of ${ }^{3} \mathrm{H}_{2} \mathrm{O}$ from $\left(3-{ }^{3} \mathrm{H}\right)$-D-glucose, an index of glycolysis, and the incorporation of ${ }^{3} \mathrm{H}$ into glycogen at $37^{\circ} \mathrm{C}$. Muscles were incubated for $60 \mathrm{~min}$ in the same buffer as indicated above, supplemented with glucose $(5 \mathrm{mmol} / 1,1 \mu \mathrm{Ci} / \mathrm{ml})$ and containing varying concentrations of insulin. At the end of incubation, ${ }^{3} \mathrm{H}_{2} \mathrm{O}$ in the medium and labelled glycogen in muscles were measured as described elsewhere [3].

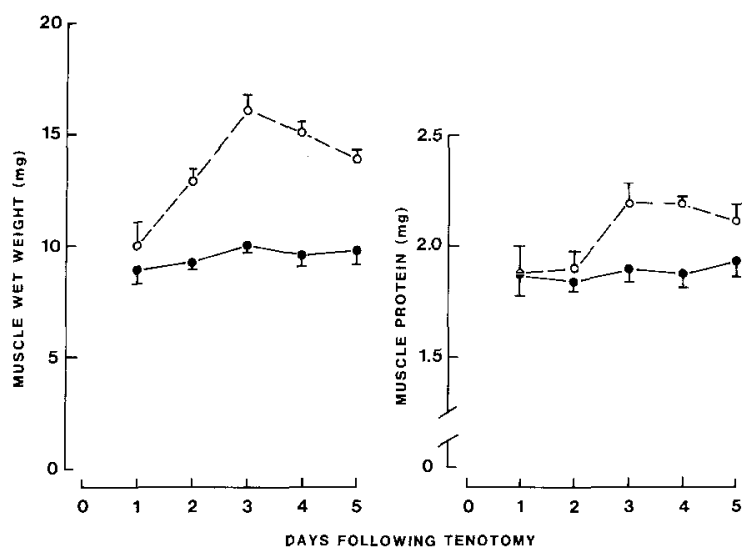

Fig. 1. Effect of tenotomy of gastrocnemius muscle on hypertrophy of soleus muscles in lean mice. Tenotomy was performed at day 0 in one leg. Soleus muscles from the operated leg (overloaded, $O_{-}-O_{\text {) }}$ and from the non-operated leg (control, - ) were removed at different period following tenotomy. Muscle wet weight was measured after removal of tendons without any incubation. Values are mean \pm SEM of five to ten muscles

\section{Glycogen synthase activation studies}

For measurement of glycogen synthase activity, muscles were incubated for $30 \mathrm{~min}$ at $37^{\circ} \mathrm{C}$ in the KRB-BSA buffer, supplemented with pyruvate $(2 \mathrm{mmol} / \mathrm{l})$ and varying concentrations of insulin. At the end of the incubation period, muscles were freeze-clamped in liquid nitrogen, and briefly $(5 \mathrm{~s})$ sonicated (Alcatel, Sonifier, France) at $0{ }^{\circ} \mathrm{C}$ in $0.5 \mathrm{ml}$ of cold buffer [Tris-buffer $(50 \mathrm{mmol} / \mathrm{l}), \mathrm{pH} 8.2$, EDTA $(5 \mathrm{mmol} / \mathrm{l})$, potassium fluoride $(100 \mathrm{mmol} / \mathrm{l})]$. After centrifugation at $10000 \mathrm{~g}$ for $5 \mathrm{~min}$ at $4^{\circ} \mathrm{C}$, synthase activity was assayed in the supernatant as described previously [5]. Glycogen synthase active form is expressed as a percentage of the total synthase activity [5].

\section{Insulin binding studies}

Muscles were incubated for $4 \mathrm{~h}$ at $20^{\circ} \mathrm{C}$ in $1 \mathrm{ml}$ of KRB-BSA buffer, supplemented with pyruvate $(2 \mathrm{mmol} / \mathrm{l})$ and containing $0.1 \mu \mathrm{Ci} / \mathrm{ml}$, ${ }^{125} \mathrm{I}$-insulin (sp. act. $200-240 \mu \mathrm{Ci} / \mu \mathrm{g}$ ). Some muscles were incubated with unlabelled insulin $(1 \mu \mathrm{mol} / 1)$ to measure non-specific binding. Muscles were then washed for $30 \mathrm{~min}$ in $\mathrm{NaCl}(154 \mathrm{mmol} / 1)$ solution, dissolved in $0.5 \mathrm{ml}$ of $\mathrm{NaOH}(1 \mathrm{~mol} / \mathrm{l})$ and counted.

\section{Measurement of intracellular and extracellular spaces}

Muscles were incubated for $10 \mathrm{~min}$ in KRB-BSA buffer containing ${ }^{3} \mathrm{H}_{2} \mathrm{O}(1 \mu \mathrm{Ci} / \mathrm{ml})$ and $\left({ }^{14} \mathrm{C}\right)$ sucrose $(0.5 \mu \mathrm{Ci} / \mathrm{ml})$. At the end of the incubation period, tendons were carefully removed, muscles were dissolved in $\mathrm{NaOH}(1 \mathrm{~mol} / 1)$ and the radioactivity measured to obtain the extracellular space $\left({ }^{14} \mathrm{C}\right.$ space $)$ and intracellular space $\left({ }^{3} \mathrm{H}\right.$ space minus ${ }^{14} \mathrm{C}$ space).

\section{Plasma determination}

When necessary, mice were anaesthetised with sodium pentobarbital ( $100 \mathrm{mg} / \mathrm{kg}$ body weight, intraperitoneally) and a blood sample was withdrawn from the retroorbital sinus. Blood samples were centrifuged at $10000 \mathrm{~g}$ for $5 \mathrm{~min}$ at $4{ }^{\circ} \mathrm{C}$ and the plasma used for determination of glucose and immunoreactive insulin with mouse insulin used as standard [3].

\section{Muscle glycogen and fructose 2-6 bisphosphate contents}

Muscle glycogen content was determined enzymatically as described elsewhere [14]. For fructose-2,6- $\mathrm{P}_{2}$ determination, muscles were sonifi-

Table 1. Characteristics of animals and soleus muscles before and 4 days after tenotomy of gastrocnemius muscles

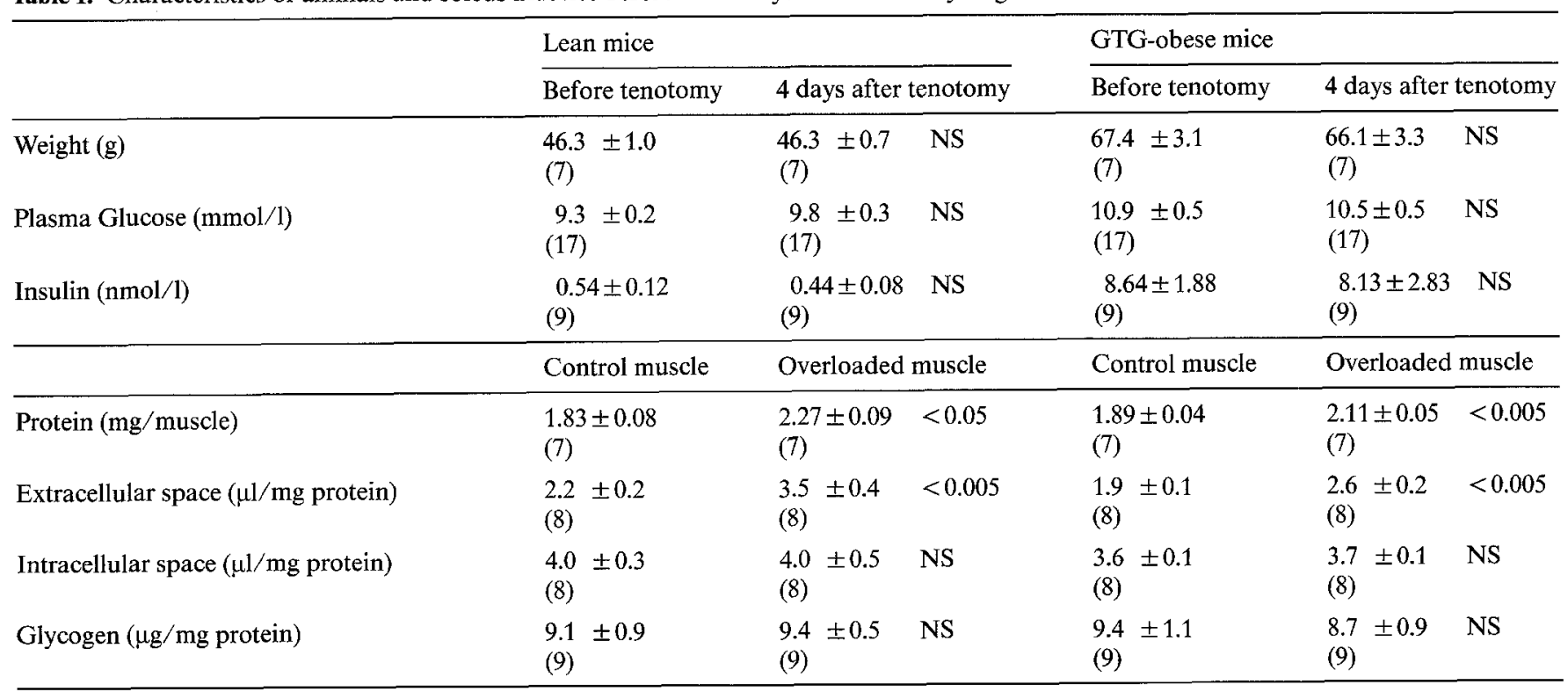




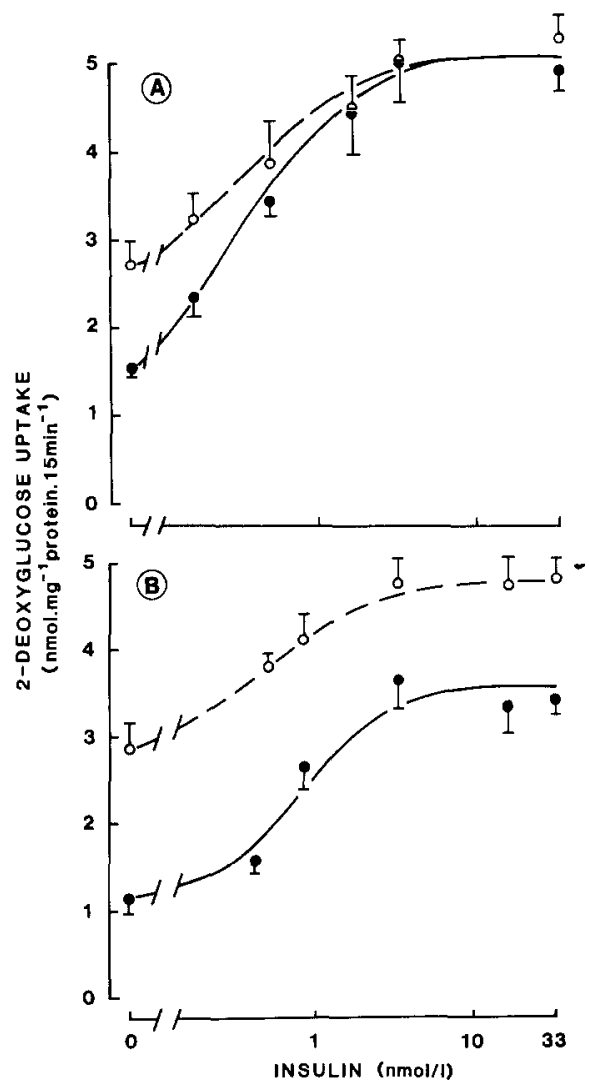

Fig. 2. Effect of work-induced hypertrophy on insulin dose response curves of deoxyglucose transport in soleus muscles of (A) lean and (B) GTG-obese mice. Overloaded $\left(\mathrm{O}-\mathrm{O}^{\mathrm{O}}\right)$ or control $(-)$ ) muscles were pre-incubated for $1 \mathrm{~h}$ in KRB-BSA buffer with varying concentration of insulin, and then incubated for $15 \mathrm{~min}$ in the same buffer containing $1-\left({ }^{14} \mathrm{C}\right)$-deoxyglucose $(0.5 \mathrm{mmol} / 1,0.1 \mu \mathrm{Ci} / \mathrm{ml})$. Each point is the mean \pm SEM of four to eight muscles

Table 2. Effect of phloridzin on deoxyglucose uptake by control and overloaded soleus muscles of lean mice

\begin{tabular}{|c|c|c|}
\hline & \multicolumn{2}{|c|}{ 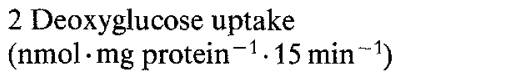 } \\
\hline & Without phloridzin & With phloridzin \\
\hline \multicolumn{3}{|l|}{ Control } \\
\hline Basal & $1.60 \pm 0.13$ & $0.46 \pm 0.02$ \\
\hline Insulin & $5.50 \pm 0.07$ & $1.01 \pm 0.11$ \\
\hline \multicolumn{3}{|c|}{ Overloaded } \\
\hline Basal & $3.22 \pm 0.42$ & $0.82 \pm 0.06$ \\
\hline Insulin & $5.15 \pm 0.23$ & $1.04 \pm 0.08$ \\
\hline
\end{tabular}

Deoxyglucose uptake was measured during a 15-min incubation period after $30 \mathrm{~min}$ pre-incubation with or without insulin $(33 \mathrm{nmol} / \mathrm{l})$, and with or without phloridzin $(5 \mathrm{mmol} / 1)$ as described in Figure 2. Each value is the mean \pm SEM of five muscles

ed in $\mathrm{NaOH}(50 \mathrm{mmol} / \mathrm{l})$ and treated at $80^{\circ} \mathrm{C}$ for $5 \mathrm{~min}$. Fructose$2,6-\mathrm{P}_{2}$ was then assayed in alkaline extracts as described previously [15].

\section{Chemicals}

Radioactive substances were purchased from Amersham International, Amersham, Bucks, UK or from New England Nuclear Chemicals, Dreieich, FRG. All other reagents were of the best grade commercially available and were obtained from Sigma, St.Louis, Miss., USA, from Merck, Darmstadt, FRG or from Boehringer, Mannheim, FRG. Monocomponent porcine insulin was a gift from Novo, Copenhagen,

\section{Calculations and statistical analysis}

An aliquot sample of alkaline solution of muscle was kept for protein determination of each individual muscle preparation, bovine serum albumin being used as standard [3]. All results are expressed per $\mathrm{mg}$ of protein and are presented as mean \pm SEM for the number of individual muscles indicated. Statistical significance was assessed by Student's t-test for paired comparisons when the overloaded muscle and the control muscle from the same animal were compared. When muscles from different animals were studied, Student's t-test for unpaired comparisons was used [16].

\section{Results}

\section{Time course of work-induced hypertrophy of soleus muscles}

Following tenotomy of the gastrocnemius muscle, the soleus muscle underwent rapid compensatory hypertrophy, the time-course and the degree of which were similar to that obtained in rats [12]. Wet weight of soleus muscles of lean mice increased by $50 \%$ within 3 days compared with the weight of the contralateral muscle (Fig.1). Similar results were obtained in muscles of GTG-obese mice (data not shown). All subsequent experiments were thus performed 4 days after tenotomy when hypertrophy was maximal. The increase in protein content due to exercise was moderate $(15 \%$ over control; Fig.1). Results were calculated per mg protein and the conclusions were identical when the results were expressed per whole muscle. The increase in muscle wet weight was mainly due to an enlargement of the extracellular space without any change in the intracellular space (Table 1). As expected, tenotomy did not modify insulinaemia, glycaemia or body weight (Table 1). GTG-obese mice remained slightly hyperglycaemic and markedly hyperinsulinaemic. Thus, we were able to study the effects of work-induced hypertrophy without any concomitant change in circulating parameters, each hypertrophied muscle being compared with the control muscle from the same animal.

\section{Effect of work-induced hypertrophy on 2-deoxyglucose uptake}

The uptake of 2-deoxyglucose by muscles was used as an index of glucose transport and phosphorylation. Overloaded muscles of lean or obese mice accumulated much more 2-deoxyglucose than control muscles in basal conditions (in the absence of insulin; Fig.2). Work-induced hypertrophy was accompanied by an inflammatory response characterized by oedema (Table 1) and leucocyte infiltration [17]. To eliminate the possibility that the increase in glucose uptake rate was a response to inflammation, muscles were pre-incubated with phloridzin $(5 \mathrm{mmol} / \mathrm{l})$ because glucose penetration occurs in granulocytes by passive diffusion which is not modified by phloridzin [18], while in muscle glucose is transported through an active process which can be inhibited by phloridzin [19]. The results presented in Table 2 show that $78 \%$ of the increase in basal glucose 
Table 3. Lack of effect of work-induced hypertrophy on ${ }^{125}$ I-insulin binding to soleus muscles of lean and goldthioglucose obese mice

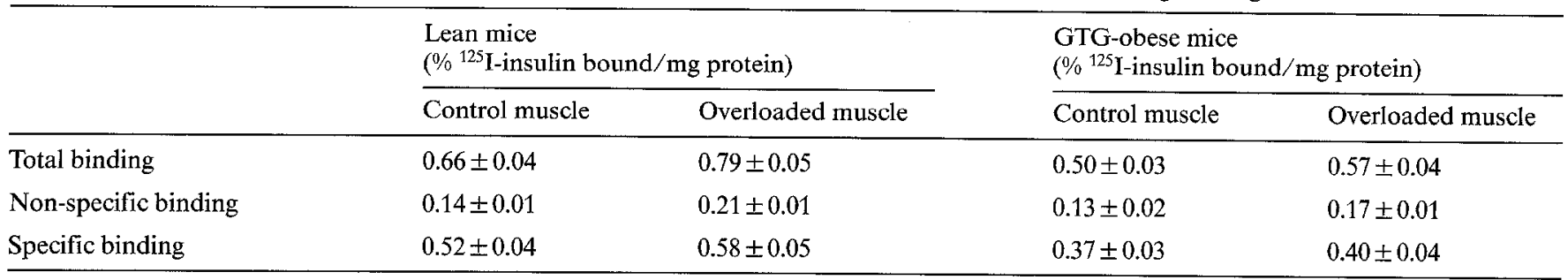

Each value is the mean \pm SEM of eight to nine muscles. Differences in specific binding between lean and GTG-obese mice were statistically significant $(p<0.02)$

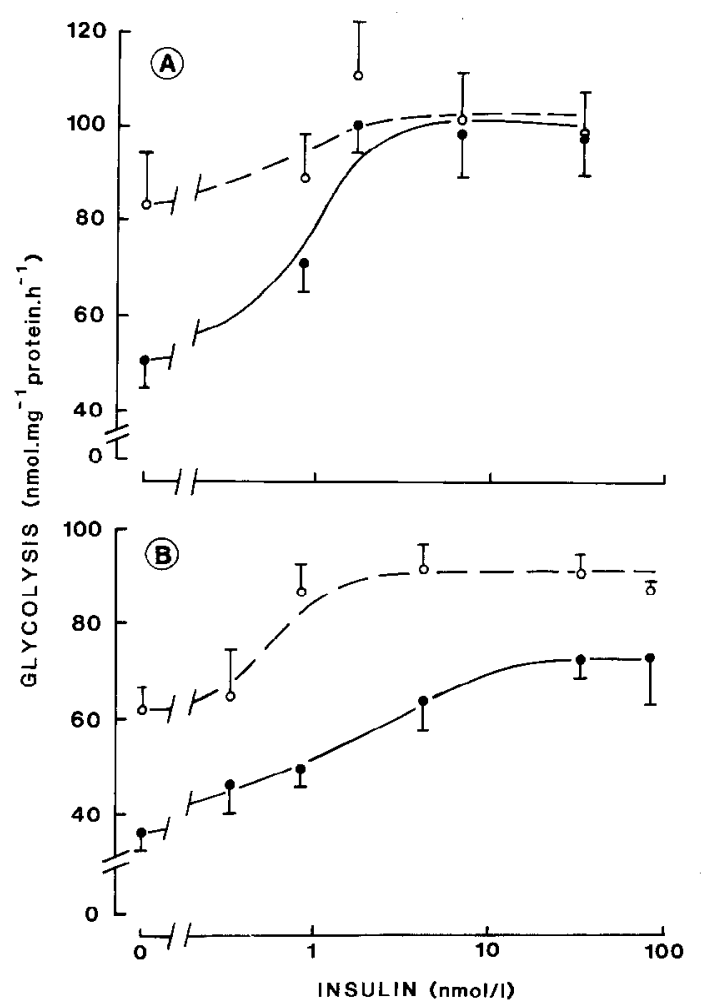

Fig.3. Effect of work-induced hypertrophy on insulin dose-response curves of glycolysis in soleus muscles of (A) lean and (B) GTG-obese mice. Overloaded $\left(\mathrm{O}_{--} \mathrm{O}\right)$ or control $(-)$ ) muscles were incubated for $1 \mathrm{~h}$ at $37^{\circ} \mathrm{C}$ in $1 \mathrm{ml} \mathrm{KRB}-B S A, 5 \mathrm{mmol} / 1\left(3-^{3} \mathrm{H}\right)$-glucose and insulin at the concentrations indicated. Each point is the mean \pm SEM of five to ten muscles

phloridzin, suggesting that this increase could not be accounted for by leucocyte infiltration.

With maximally stimulating insulin concentrations, deoxyglucose transport was similar in control and overloaded muscles of lean mice (Fig. 2). The pattern observed in GTG-obese mice was different in that 2-deoxyglucose uptake was increased in overloaded muscles even at maximally effective insulin concentrations (Fig. 2). When the results were expressed as a percentage of maximal insulin effect, the dose response curves obtained in overloaded and control muscles of lean mice were superimposable (data not shown). However, it should be noted that the determination of halfmaximally effective concentration $\left(\mathrm{EC}_{50}\right)$ was obscured by the low amplitude of insulin effect in overloaded muscles. As already reported [3], control muscles of GTG-obese mice were less sensitive to insulin $\left(\mathrm{EC}_{50} \simeq\right.$ $0.8 \mathrm{nmol} / \mathrm{l})$ than control muscles of lean mice $\left(\mathrm{EC}_{50} \simeq\right.$
$0.4 \mathrm{nmol} / 1)$. Furthermore, work-induced hypertrophy did not modify insulin sensitivity of muscles from obese mice $\left(\mathrm{EC}_{50} \simeq 1 \mathrm{nmol} / \mathrm{l}\right)$.

\section{Effect of work-induced hypertrophy on insulin binding to soleus muscles}

Total binding of ${ }^{125} \mathrm{I}$-insulin was slightly increased in hypertrophied compared with control muscles (Table 3). This increase could be accounted for entirely by a more important proportion of non-specific binding (due to a larger extracellular space). Thus, specific binding was not modified in overloaded muscles. As described earlier [3], muscles of obese mice bound less insulin than muscles of lean mice (Table 3 ).

\section{Effect of work-induced hypertrophy on glucose metabolism in muscles}

The fate of glucose taken up by the muscle through glycolysis and glycogen synthesis was then measured. Glycolysis reflected the results obtained for 2-deoxyglucose uptake: basal values were markedly increased in overloaded muscle compared with control in both groups of mice (Fig.3). In the presence of maximally-effective insulin concentrations, glycolysis was identical in control and overloaded muscles of lean mice, while in GTGobese mice, overloaded muscles displayed higher glycolytic rates than their controls. The values reached in muscles of GTG-obese mice were similar to the maximal values obtained in lean mice. Insulin sensitivity of the glycolytic pathway seemed higher in overloaded muscles of GTG-obese mice than in controls, but this apparent difference was difficult to appreciate because of the low amplitude of the insulin effect, due to the high basal values.

Glycogen synthesis was decreased at all insulin concentrations tested in overloaded muscles compared with control muscles (Fig. 4, the difference observed in basal conditions was not statistically significant). This was observed whatever the length of incubation between 15 and $60 \mathrm{~min}$ (data not shown). This decrease in glycogen synthesis cannot be attributed to a change in muscle glycogen content since this parameter was not modified in hypertrophied muscle (Table 1). Total glucose metabolism, as estimated by the sum of glycogen synthesis and glycolysis paralleled 2-deoxyglucose uptake, although differences in maximally insulin-stimu- 


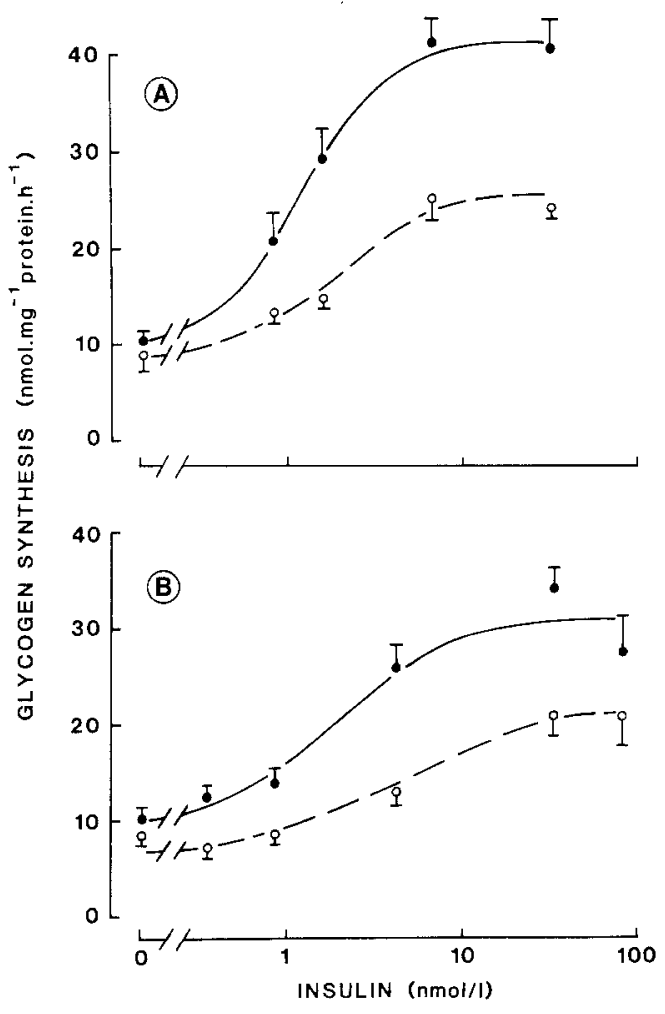

Fig.4. Effect of work-induced hypertrophy on insulin dose-response curves of glycogen synthesis in soleus muscles of (A) lean and (B) GTG-obese mice. Overloaded $\left(\mathrm{O}_{-} \mathrm{O}_{\mathrm{O}}\right)$ and control $(-)$ ) muscles were incubated as described in Figure 3. Each point is the mean $\pm \mathrm{SEM}$ of four to ten muscles

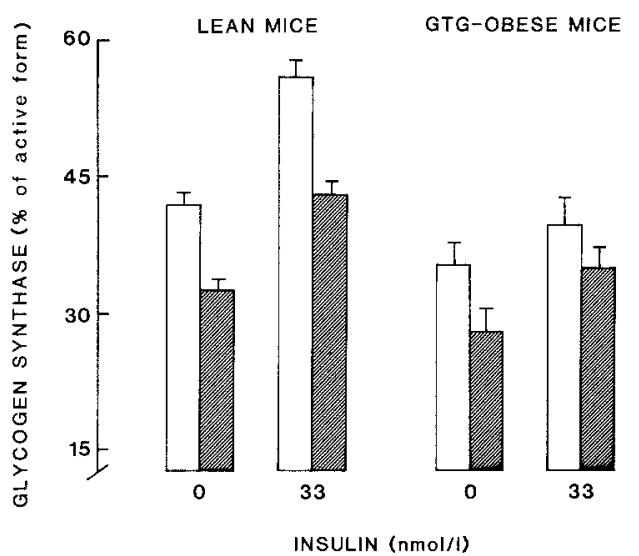

Fig. 5. Effect of work-induced hypertrophy on glycogen synthase activity in soleus muscles of lean and GTG-obese mice. Control $(\square)$ or overloaded ( $\boldsymbol{\square})$ muscles were incubated for $30 \mathrm{~min}$ in KRB-BSA buffer with or without insulin. Results are mean \pm SEM of eight (GTGobese) or 15 (lean) muscles

lated values between overloaded and control muscles from obese mice did not reach a level of statistical significance due to the large standard errors (data not shown).

Resistance of glycogen synthesis to stimulation by insulin could result from the inability of insulin to activate the glycogen synthase. Glycogen synthase activation has been shown in muscle to occur via a mechanism independent of the hormone's effect on glucose transport $[14,20]$. The effect of insulin on glycogen synthase activity in muscles incubated in the absence of
Table 4. Effect of work-induced hypertrophy on fructose-2,6- $\mathrm{P}_{2}$ content of soleus muscles of lean and GTG-obese mice

\begin{tabular}{|c|c|c|c|c|}
\hline \multirow{3}{*}{$\begin{array}{l}\text { Incubation } \\
\text { condition }\end{array}$} & \multicolumn{4}{|c|}{ Fructose- $2,6-\mathrm{P}_{2}$ content (nmol/g protein) } \\
\hline & \multicolumn{2}{|c|}{ Lean mice } & \multicolumn{2}{|c|}{ GTG-obese mice } \\
\hline & $\begin{array}{l}\text { Control } \\
\text { muscle }\end{array}$ & $\begin{array}{l}\text { Overloaded } \\
\text { muscle }\end{array}$ & $\begin{array}{l}\text { Control } \\
\text { muscle }\end{array}$ & $\begin{array}{l}\text { Overloaded } \\
\text { muscle }\end{array}$ \\
\hline No incubation & $\begin{array}{l}2.0 \pm 0.3 \\
(24)\end{array}$ & $\begin{array}{l}16.7 \pm 3.1 \\
(5)\end{array}$ & $\begin{array}{l}1.4 \pm 0.3 \\
(18)\end{array}$ & $\begin{array}{l}14.8 \pm 1.3 \\
(5)\end{array}$ \\
\hline $\begin{array}{l}\text { Glucose } \\
\qquad(5 \mathrm{mmol} / 1)\end{array}$ & $\begin{array}{l}4.9 \pm 1.9 \\
(6)\end{array}$ & $\begin{array}{l}10.4 \pm 1.7 \\
(8)\end{array}$ & $\begin{array}{l}5.7 \pm 1.3 \\
(4)\end{array}$ & $\begin{array}{l}19.4 \pm 6.3 \\
(5)\end{array}$ \\
\hline $\begin{array}{l}\text { Glucose } \\
\qquad \begin{array}{l}(5 \mathrm{mmol} / \mathrm{l}) \\
+ \text { insulin } \\
(33 \mathrm{nmol} / 1)\end{array}\end{array}$ & $\begin{array}{l}4.5 \pm 0.7 \\
(8)\end{array}$ & $\begin{array}{l}12.5 \pm 1.1 \\
(8)\end{array}$ & $\begin{array}{l}5.6 \pm 0.9 \\
(5)\end{array}$ & $\begin{array}{l}18.6 \pm 1.1 \\
(5)\end{array}$ \\
\hline
\end{tabular}

Values are expressed as mean \pm SEM of the number of muscles indicated in parentheses

thase activity ratio was decreased both in overloaded muscles of lean and GTG-obese mice. When muscles from lean mice were incubated with a maximally effective insulin concentration, the change in percentage active form was $15 \%$ in control muscles and $11 \%$ in overloaded muscles and thus the value reached with insulin in hypertrophied muscles was much lower than that obtained in control muscles. Furthermore, total glycogen synthase activity was lower in overloaded muscles than in control muscles $(14.9 \pm 2.0$ versus $24.5 \pm 0.9 \mathrm{nmol}$. $\mathrm{min}^{-1} \cdot \mathrm{mg}^{-1}$ protein, mean $\pm \mathrm{SEM}$ of seven values). In control muscles of GTG-obese mice, insulin had a very small effect in activating glycogen synthase, and workinduced hypertrophy did not modify this response. In those animals also, hypertrophy resulted in a decreased total glycogen synthase activity $(25.7 \pm 1.4$ and $19.6 \pm$ $1.2 \mathrm{nmol} \cdot \mathrm{min}^{-1} \cdot \mathrm{mg}^{-1}$ protein, mean $\pm \mathrm{SEM}$ of seven control and overloaded muscles, respectively).

\section{Effect of work-induced hypertrophy on fructose-2,6- $P_{2}$ content of muscle}

Fructose-2,6- $\mathrm{P}_{2}$ has recently been shown to be a potent stimulator of phosphofructokinase [21] and changes in its concentration have been related to changes in glycolytic fluxes. We therefore looked for fructose-2,6- $\mathrm{P}_{2}$ content in overloaded and control muscles (Table 4). Fructose-2,6- $\mathrm{P}_{2}$ content measured in muscles without any prior incubation was increased almost ten times in overloaded compared with control muscles (no difference was observed between lean and GTG-obese mice). Incubation with glucose or glucose + insulin more than doubled fructose-2,6- $\mathrm{P}_{2}$ content in control muscles, but had no effect in overloaded muscles.

\section{Discussion}

In soleus muscles of lean mice, the first effect of workinduced hypertrophy was to stimulate markedly glucose uptake and phosphorylation. Following tenotomy of 
cle undergoes rapid compensatory growth. This fibre enlargement presumably represents the response of the muscle to elevated contractile demands and/or stretch placed on the muscle by removal of the synergists [22]. The increase in glucose uptake may be due to passive stretch rather than, or in addition to, an increase in activity. A persistent increase in permeability to sugar appears to be a general physiological response of skeletal muscles to exercise, e.g., electric stimulation of sciatic nerve produced a tenfold increase in the rate of glucose uptake [23, 24]. Decreased muscle glycogen content seems to be a major determinant of increased glucose uptake [25]. When glycogen content was moderately depleted only, glucose uptake was similar in the hindquarters of exercised and control rats [10]. In our study, increased deoxyglucose uptake and phosphorylation cannot be attributed to depleted glycogen depots, since skeletal muscle glycogen levels showed no differences between control and overloaded muscles. Thus, other factors are probably involved in the increase in glucose uptake during exercise in muscle.

Glucose, which is taken up at a higher rate in overloaded muscle, is preferentially directed through the glycolytic pathway $[26,27]$. Glycolysis is mainly regulated in liver and muscle at the level of phosphofructokinase. In liver, fructose-2,6- $\mathrm{P}_{2}$ has recently be described to be the most potent positive effector of this enzyme [21], but few studies have been performed in muscle. We have found that in exercised muscles, the concentration of fructose-2,6- $\mathrm{P}_{2}$ increases almost tenfold, an increase which could be responsible for the marked stimulation of the glycolytic flux observed in the same muscles. Incubation of control muscles with glucose also increased fructose-2,6- $\mathrm{P}_{2}$ content, but no further additional effect of insulin was observed. It is likely that fructose-2,6- $\mathrm{P}_{2}$ plays a major role in controlling muscle glycolysis, as in liver [21]. This finding is at variance with the results obtained in hind limb perfused muscle, in which electrical stimulation decreased fructose-2,6- $\mathbf{P}_{2}$ content [28]. This could be due to the fact that in the conditions used muscles were tetanized.

When overloaded muscles of lean mice were incubated with maximally effective insulin concentrations, no additive effects of work-induced hypertrophy and insulin were observed for either glucose uptake and phosphorylation or glycolysis. Furthermore, no changes in insulin sensitivity or insulin binding could be observed in overloaded compared with control muscles. Glycogen synthesis was decreased in exercised muscles of lean mice in response to submaximal or maximal insulin concentrations compared with control muscles. This appears not to be due to an increase in glycogen content in muscles before the incubation period. It is more likely the consequence of a decrease of both the percentage of glycogen synthase active form and the total amount of the enzyme.

In accordance with previously reported results [1-3,5], control muscles of GTG-obese mice displayed abnormalities of glucose transport and metabolism, decreased responsiveness and sensitivity to insulin. Thus, tenotomy of the gastrocnemius muscle of one leg did not modify the usual insulin resistance observed in muscles of GTG-obese mice in the contralateral non-operated leg. Work-induced hypertrophy (in the absence of insulin) produced the same effects in GTG-obese mice as in lean mice. Basal deoxyglucose uptake and phosphorylation and glycolysis were markedly increased, and fructose-2,6- $\mathrm{P}_{2}$ content was more than tenfold higher in overloaded muscles.

Opposite to the results observed in lean muscles, the effects of overload plus insulin were larger than the effects of insulin alone on glucose uptake and glycolysis. With maximal concentrations of insulin, the values obtained in overloaded muscles of GTG-obese mice reached those in lean mice. Thus, work-induced hypertrophy was able to compensate for decreased insulin responsiveness observed in GTG-obese muscles. Additive effects of insulin and work induced by pressure were also observed in perfused hearts from obese Zucker rats [29]. The mechanisms of such effects of exercise are unknown. In rat diaphragm, insulin stimulates glucose transport through a translocation of functionnally identical glucose transport systems from an intracellular pool to the plasma membrane [30]. It has been shown that, in insulin-resistant states induced by high fat diet or ageing [31, 32] decreased glucose transport in adipocytes correlates with a decreased pool of intracellular glucose carriers. It is possible that such a mechanism occurs in the muscle of obese mice. Workinduced hypertrophy would increase the pool of intracellular glucose transport systems which are then able to be recruited by insulin. By contrast, the decreased insulin sensitivity (i.e. the decreased response to submaximally effective insulin concentrations) was not alleviated by exercise. The observation that work-induced hypertrophy did not result in any change in muscle sensitivity to the hormone was supported by the finding that no change occurred in insulin binding which remained decreased in GTG-obese mice. This result is in agreement with the observations that in soleus muscles of genetically obese Zucker rats [8] or in perfused hind limbs of old Zucker rats [7] exercise did not increase insulin sensitivity. Finally, work-induced hypertrophy did not appear to reverse an intracellular defect observed in muscles of GTG-obese mice. Insulin was as ineffective in activating glycogen synthase in control and overloaded muscles of GTG-obese mice.

In conclusion, work-induced hypertrophy is able to compensate for the insulin-resistant state observed in isolated muscles of obese mice, without correcting all the defects observed in this tissue. There is an increase in glucose uptake and glycolysis, both in the absence or presence of maximal insulin concentrations without any modification of insulin binding or insulin sensitivity.

Acknowledgements. This study was presented in part at the 20th Annual Meeting of the European Association for the Study of Diabetes, London, September 1984. We are greatly indebted to N. Grenier-Brossette, T.Gremeaux, G.Visciano and R.M.Faes for their excellent 
technical help and illustration work, and to J. Duch and L. Capolongo for their secretarial assistance. This work was supported by Grant MIR 83C 0447, by research funds from Institut National de la Santé et de la Recherche Médicale (France) et Grant 3.851.0.83. SR from Swiss National Science Foundation (Berne, Switzerland).

\section{References}

1. Cuendet GS, Loten EG, Jeanrenaud B, Renold AE (1976) Decreased basal, noninsulin-stimulated glucose uptake and metabolism by skeletal soleus muscle isolated from obese-hyperglycemic (ob/ob) mice. J Clin Invest 58: 1078-1088

2. Crettaz M, Prentki M, Zaninetti D, Jeanrenaud B (1980) Insulin resistance in soleus muscle from obese Zucker rats. Involvement of severel defective sites. Biochem J 186: 524-534

3. Le Marchand-Brustel Y, Jeanrenaud B, Freychet P (1978) Insulin binding and effects in isolated soleus muscle of lean and obese mice. Am J Physiol 234: E348-E358

4. Le Marchand-Brustel Y, Moutard N, Freychet P (1982) Aminoisobutyric acid transport in soleus muscles of lean and goldthioglucose obese mice. Am J Physiol 243: E74-E79

5. Le Marchand-Brustel Y, Freychet P (1980) Alteration of glycogen synthase activation by insulin in soleus muscles of obese mice. FEBS Lett 120: 205-208

6. Berger M, Kemmer FW, Becker K, Herberg L, Schwenen M, Gjinavci A, Berchtold P (1979) Effect of physical training on glucose tolerance and on glucose metabolism of skeletal muscle in anaesthetized normal rats. Diabetologia 16:179-184

7. Becker-Zimmermann K, Berger M, Berchtold P, Gries FA, Herberg L, Schwenen M (1982) Treadmill training improves intravenous glucose tolerance and insulin sensitivity in fatty Zucker rats. Diabetologia 22: 468-474

8. Crettaz M, Horton ES, Wardzala LJ, Horton ED, Jeanrenaud B (1983) Physical training of Zucker rats: lack of alleviation of muscle insulin resistance. Am J Physiol 244: E414-E420

9. Mondon CE, Dolkas CB, Reaven GM (1980) Site of enhanced insulin sensitivity in exercise-trained rats at rest. Am J Physiol 239: E169-E177

10. Richter EA, Garetto LP, Goodman MN, Ruderman NB (1982) Muscle glucose metabolism following exercise in the rat. Increased sensitivity to insulin. J Clin Invest 69:785-793

11. Espinal J, Dohm GL, Newsholme EA (1983) Sensitivity to insulin of glycolysis and glycogen synthesis of isolated soleus-muscle strips from sedentary, exercised and exercise-trained rats. Biochem J 212: 453-458

12. Goldberg AL, Etlinger JD, Goldspink DF, Jablecki C (1975) Mechanism of work-induced hypertrophy of skeletal muscle. Med Sci Sports 7: 248-261

13. Dawson RMC, Elliott DC, Elliott WH, Jones KM (eds) (1969) Data for biochemical research, 2nd edn. Clarendon Press, Oxford, p 507

14. Le Marchand-Brustel Y, Freychet $P$ (1981) Regulation of glycogen synthase activity in the isolated mouse soleus muscle. Effect of insulin, epinephrine, glucose and anti-insulin receptor antibodies. Biochim. Biophys. Acta 677: 13-22

15. Van Schaftingen E, Lederer B, Bartrons R, Hers HG (1982) A kinetic study of pyrophosphate: fructose-6-phosphate phosphotransferase from potato tubers. Application to a microassay of Fructose 2,6-bisphosphate. Eur J Biochem 129: 191 - 195

16. Snedecor GW, Cochran WG (1967) Statistical methods, 6th edn. Iowa State University Press, Ames
17. Armstrong RB, Marum P, Tullson P, Saubert CW IV. (1979) Acute hypertrophic response of skeletal muscle to removal of synergists. J Appl Physiol Respir Environ Exercise Physiol 46: 835-842

18. Leroux JP, Marchand JC, Hong Tuan Ha R, Cartier P (1975) The influence of insulin on glucose permeability and metabolism of human granulocytes. Eur J Biochem 58: 367-373

19. Le Marchand-Brustel Y, Freychet $P$ (1979) Effect of fasting and streptozotocin diabetes on insulin binding and action in the isolated soleus muscle. J Clin Invest 64: 1505-1515

20. Oron Y, Larner J (1980) Insulin action in intact mouse diaphragm I. Activation of glycogen synthase through stimulation of sugar transport and phosphorylation. Mol Cell Biochem 32: 153-160

21. Hers HG, Van Schaftingen E (1982) Fructose 2,6-bisphosphate 2 years after its discovery. Biochem J 206: 1-12

22. Goldspink DF, Garlick PJ, McNurlan MA (1983) Protein turnover measured in vivo and in vitro in muscles undergoing compensatory growth and subsequent denervation atrophy. Biochem J 210: $89-98$

23. Berger M, Hagg SA, Goodman MN, Ruderman NB (1976) Glucose metabolism in perfused skeletal muscle. Effect of starvation, diabetes, fatty acids, acetoacetate, insulin, and exercise on glucose uptake and disposition. Biochem J 158: 191-202

24. Walker PM, Idström JP, Scherstén T, Bylund-Fellenius AC (1982) Glucose uptake in relation to metabolic state in perfused rat hind limb at rest and during exercise. Eur J Appl Physiol 48: 163-176

25. Fell RD, Terblanche SE, Ivy JL, Young JC, Holloszy JO (1982) Effect of muscle glycogen content on glucose uptake following exercise. J Appl Physiol Respir Environ Exercise Physiol 52: 434-437

26. Newsholme EA (1979) The control of fuel utilization by muscle during exercise and starvation. Diabetes 28 (Suppl 1): 1-7

27. Ruderman NB, Goodman MN, Conover CA, Berger M (1979) Substrate utilization in perfused skeletal muscle. Diabetes 28 (Suppl 1): 13-17

28. Hue L, Blackmore PF, Shikama H, Robinson-Steiner A, Exton JH (1982) Regulation of fructose-2,6-bisphosphate content in rat hepatocytes, perfused hearts, and perfused hindlimbs. J Biol Chem 257: 4308-4313

29. Zaninetti D, Crettaz M, Jeanrenaud B (1983) Dysregulation of glucose transport in hearts of genetically obese $(f a / f a)$ rats. Diabetologia 25: $525-529$

30. Wardzala LJ, Jeanrenaud B (1981) Potential mechanism of insulin action on glucose transport in the isolated rat diaphragm. Apparent translocation of intracellular transport units to the plasma membrane. J Biol Chem 256: 7090-7093

31. Hissin PJ, Foley JE, Wardzala LJ, Karnieli E, Simpson IA, Salans LB, Cushman SW (1982) Mechanism of insulin-resistant glucose transport activity in the enlarged adipose cell of the aged, obese rat. Relative depletion of intracellular glucose transport systems. J Clin Invest 70: 780-790

32. Hissin PJ, Karnieli E, Simpson IA, Salans LB, Cushman SW (1982) A possible mechanism of insulin resistance in the rat adipose cell with high-fat/low-carbohydrate feeding. Depletion of intracellular glucose transport systems. Diabetes 31: 589-592

Received: 1 November 1984

and in revised form: 28 March 1985

Dr. Y.Le Marchand-Brustel

INSERM U 145

Faculté de Médecine

Chemin de Vallombrose

F-06034 Nice Cedex

France 